\title{
HLA DQB1*03 Genotypes and Susceptibility to Cervical Cancer in Indian Women
}

\author{
Paramita Bhattacharya and Sharmila Sengupta ${ }^{1}$ \\ Human Genetics Unit, Indian Statistical Institute, Kolkata 700 108, West Bengal, India
}

\begin{abstract}
KEYWORDS Cervical cancer; human papillomavirus; HLA DQB1*03 genotypes; age of subjects
ABSTRACT DNA from i) fresh tissues derived out of 89 women with $\mathrm{CaCx}$ (61 HPV16/18 positive) and ii) cervical scrapes from 213 cytologically normal women (73 HPV16/18 positive) were genotyped for HLA DQB $1 * 03$ by PCR and RFLP. The distribution of the genotypes of HLA DQB $1 * 03$ differed significantly between the malignant and control subjects $(\mathrm{p}=0.002)$. The homozygous genotype was overrepresented among those having $\mathrm{CaCx}\left(\mathrm{OR}_{\mathrm{a}}\right.$ $=2.94,95 \% \mathrm{CI}=1.49-5.81, \mathrm{p}=0.002)$, or $\mathrm{HPV} 16 / 18$ positive $\mathrm{CaCx}(\mathrm{OR} \quad \mathrm{ar}$. $\mathrm{p}=0.033$ ), when this was compared to the other genotypes (HLADQB $1 * 03$ non-homozygous, i.e. heterozygous and null together). Analysis restricted to the HPV16/18 positive $\mathrm{CaCx}$ and cytologically normal subjects failed to show such association. The heterozygous genotype, instead, showed a negative association with HPV16/18 positive $\mathrm{CaCx}$ over the null genotype $\left(\mathrm{OR}_{\text {age-adjusted }}=0.42,95 \% \mathrm{CI}=0.18-0.96 ; \mathrm{p}=0.040\right)$ when HPV16/18 positive $\mathrm{CaCx}$ cases were compared with HPV negative cytologically normal controls. The association of HLA DQB $1 * 03$ homozygosity with $\mathrm{CaCx}$ was noted among those of age $<47$ years. The genotypes of HLA DQB1*03 are likely to be important in determining the susceptibility to HPV or HPV16/18 related $\mathrm{CaCx}$ in Indian women.
\end{abstract}

\section{INTRODUCTION}

Exposure to high-risk human papillomavirus (HPV) is common among sexually active women (Villa 1997). However, only a small fraction develops persistent infection, which may progress to cervical cancer $(\mathrm{CaCx})$ after a long latency. Therefore, additional factors seem to play important role in the pathogenesis of the infection and subsequent development of $\mathrm{CaCx}$.

In recent times, identifying genetic factors that could influence the pathogenesis of human papillomavirus infection, specifically HPV16/18 related $\mathrm{CaCx}$ has gained importance for devising preventive strategies for the disease. Therefore, such studies are essential for targeting cervical screening to a high-risk population, particularly in the developing countries, where $\mathrm{CaCx}$ still poses a big threat.

A likely factor involved in the differential susceptibility to HPV infections seems to be immunogenetic. This has been indicated by the over representation of HPV-related cervical lesions in immunosuppressed individuals (Villa 1997). Human Leukocyte Antigens (HLAs) play a pivotal role in the recognition and presentation

${ }^{1}$ Address for correspondence: Sharmila Sengupta, Ph.D, Human Genetics Unit Indian Statistical Institute

203, B.T. Road, Kolkata 700 108, West Bengal, India. Telephone: 91332577 2088; ext. 3242

Fax: 91332577 6680/3049

Email:sharmila@ isical.ac.in/sarmilasg@hotmail.com of foreign antigens to the immune system. Thus the ability of an individual to mount an immune response against viral infections and/or tumors strongly depends on the detection and elimination of infected/neoplastic cells by presentation of tumour specific and/or tumor associated antigens by the HLA molecules to T cells.

There are contradictory reports regarding the relation between polymorphic HLA genes and $\mathrm{CaCx}$. Although various reports suggest a close link between certain HLA haplotypes and $\mathrm{CaCx}$, the specific HLA alleles associated with it differ among various study groups. It has been suggested that women carrying HLA DQw3 antigen encoded by DQB $1 * 03$, are predisposed to develop $\mathrm{CaCx}$ (Wank and Thomssen 1991). While several reports have been put forward in support of this finding (Helland et al. 1992, 1994; Gregoire et al. 1994; Odunsi et al. 1995; Nawa et al. 1995; Montoya et al. 1998) there are contradictory reports that show no such association (Glew et al. 1992, 1993; Apple et al. 1994; Allen et al. 1996).

In India, $\mathrm{CaCx}$ ranks as number one among the female cancers. There is a lack of data on the prevalence of various HLA alleles and their association with $\mathrm{CaCx}$, in this part of our country. Therefore, in this study, we restricted ourselves in determining the prevalence of the candidate HLA DQB1*03 allele (corresponding to HLA DQw3 antigen) together with the genotypes and 
analyzing their association, if any, with HPV16/ 18 related $\mathrm{CaCx}$ among Indian women.

\section{MATERIALS AND METHODS}

Samples and Subjects: We used DNA isolated from, (i) tissues that were derived from 89 women with suspected malignancy (sub-sequently confirmed by histopathology as squamous cell carcinoma) of age 26-75 years, who were attending a cancer referral hospital; and (ii) from 96 (HPV positive) and 117 (HPV negative) cervical scrapes. The scrapes (identified as normal from Pap smear tests) were derived from women aged 16-70 years (HPV positive) and 19-80 years (HPV negative), with no previous history of cervical dysplasia/ malignancy. These women were attending a Reproductive and Child Health Clinic (Child in Need Institute, South 24 Parganas, West Bengal, India) for routine contraception and reproductive healthcare counseling. All samples (biopsy tissues and cervical scrapes) were collected from the participants with informed consent approved by the institutional ethical committee for human experimentation. A standardized questionnaire was canvassed on all by to obtain demographic and other relevant information.

All DNA samples were routinely typed for the presence of HPV infection. Among the 89 CaCx samples, 61 (68.54\%) samples were found to be positive for HPV16 or 18, collectively termed the HPV16/18 group. Of the $96 \mathrm{HPV}$ positive normal DNA samples, $73(76.0 \%)$ were positive for HPV types $16 / 18$ out of which, 70 subjects were positive for HPV types 16 alone, 6 subjects for type 18 alone and 3 for both 16 and 18 .

HLA Typing: HLA DQB $1 * 03$ typing was done following the method of Mehal et al. (1994) with modifications. The $39^{\text {th }}$ and $40^{\text {th }}$ codons of both HLA DQB $1 * 03$ and non- HLA DQB $1 * 03$ alleles are CGC and TTC respectively. A mutagenesis primer was used to mutate the first base of codon 40 from $\mathrm{T}$ to $\mathrm{G}$. This creates a MluI site, specific for HLA DQB $1 * 03$ alleles having an A at the third base of codon 38 , in contrast to $\mathrm{G}$ in case of non- HLA DQB $1 * 03$ alleles. PCR was thus carried out using the mutagenesis primer and an upstream primer DB130 (Bugawan and Erlich 1991) in $10 \mathrm{ml}$ reaction volume using $1 \mathrm{ml}$ of $10 \mathrm{X}$ supplied PCR buffer (without $\mathrm{MgCl}_{2}$ ), $1.5 \mathrm{mM}$ $\mathrm{MgCl}_{2} 200 \mathrm{mM}$ dNTPs, $20 \mathrm{ng}$ of each primer, 0.5 U Taq DNA Polymerase and 100 ng DNA. Thirty cycles of amplification reactions were carried out, preceded by an initial denaturation at $94{ }^{\circ} \mathrm{C}$ for $8 \mathrm{~min}$ and followed by $5 \mathrm{~min}$ of final extension at $72{ }^{\circ} \mathrm{C}$. Each cycle included $1 \mathrm{~min}$ denaturation at $94{ }^{\circ} \mathrm{C}, 1 \mathrm{~min}$ annealing at $60{ }^{\circ} \mathrm{C}$ and $1 \mathrm{~min}$ elongation at $72{ }^{\circ} \mathrm{C}$. PCR products were digested overnight with $\mathrm{MluI}$ at $37^{\circ} \mathrm{C}$, separated on a $2 \%$ agarose gel by electrophoresis and visualized under UV light after staining with ethidium bromide.

Statistical Analysis: The histopathologically confirmed $\mathrm{CaCx}$ cases, either all (irrespective of HPV infection status) or HPV16/18 positive, were compared with the cytologically normal HPV negative controls. Similar analyses were also carried out within HPV16/18 positive cases and controls. Furthermore, since it is proposed that close to $99.7 \% \mathrm{CaCx}$ cases are HPV positive (Walboomers et al. 1999), all such cases were also compared with HPV positive cytologically normal samples.

In this study, the $\mathrm{CaCx}$ cases $(n=89)$ were significantly older (mean age, $47.76 \pm 11.91$ years) than HPV negative cytologically normal controls (mean age: $37.41 \pm 13.44$ years). The mean age of HPV16/18 positive CaCx cases $(n=61)$ was also significantly higher (Mean age, $48.53 \pm 12.78$ years) than the cytologically normal controls, either HPV negative or HPV16/18 positive (mean age: $27.15 \pm 8.67$ years). Also, between the latter two groups, the HPV16/18 positive cytologically normal subjects were found to be significantly younger than those HPV negatives. Therefore multivariate logistic regression analyses were performed using the SPSS 7.5 statistical software package to compute the age-adjusted OR (95\% CI) values (Hosmer and Lemeshow 1989), wherever necessary.

Analyses were also carried out with $\mathrm{CaCx}$ subjects stratified into cases with age $<47$ years and ${ }^{3} 47$ years, respectively, based on the median age of onset (47 years) of $\mathrm{CaCx}$, in this population.

\section{RESULTS}

The distribution of HLA DQB $1 * 03$ allele across various study groups is presented in Table 1. The prevalence of the allele was at the same level among $\mathrm{CaCx}$ cases, irrespective of HPV $(78.0 \%, \mathrm{n}=89)$ and the HPV negative controls $(80.0 \%, n=117)$. On testing for the equality of distribution of the HLADQB $1 * 03$ genotypes (homozygous, heterozygous and null) among 
these cases $(21.3 \%, 40.4 \%$ and $38.2 \%$, respectively) and controls $(19.7 \%, 58.1 \%$ and $22.2 \%$, respectively), a significant deviation was observed between the two groups $(\mathrm{df}=2, \mathrm{p}=$ 0.022). Compared to the null genotype, the homozygous genotype of HLA DQB $1 * 03(\mathrm{OR}$ adjusted $=2.50 ; 95 \% \mathrm{CI}=0.94-6.66 ; \mathrm{p}=0.066)$, but not the heterozygous genotype $(\mathrm{OR}$ age-adjusted $=$ $0.59,95 \% \mathrm{CI}=0.27-1.29 ; \mathrm{p}=0.187)$, was proportionately higher among $\mathrm{CaCx}$ cases, although not statistically significant as shown in Table 2. The overrepresentation of the homozygous genotype among those having $\mathrm{CaCx}$ was significant $\left(\mathrm{OR}_{\text {age-adjusted }}=2.94,95 \% \mathrm{CI}=\right.$ $1.49-5.81, p=0.002)$, when this genotype was compared to the other genotypes (HLADQB $1 * 03$ non-homozygous, i.e. heterozygous and null together). Similar analysis also revealed that

Table 1: Distribution of HLADQB1*03 genotypes within different cytological/histological groups with consideration of their HPV infection status

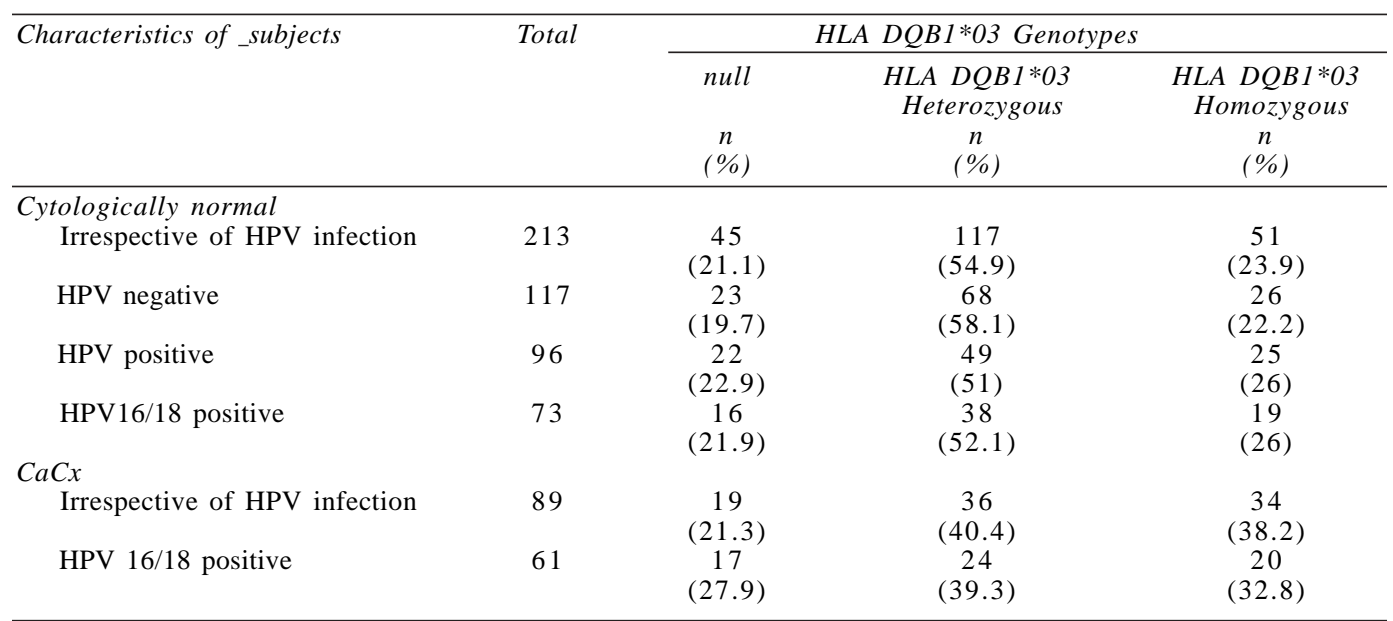

Table 2: Association of HLA DQB $1 * 03$ allele and its genotypes with $\mathrm{CaCx}$ in Indian women

\begin{tabular}{|c|c|c|c|c|}
\hline Control & Case & HLA DQB $1 * 03$ allelel genotypes compared & $\begin{array}{l}\text { Age-adjusted } \\
\text { OR }(95 \% \text { CI })\end{array}$ & p-value \\
\hline \multirow[t]{2}{*}{$\begin{array}{l}\text { HPV } \\
\text { negative } \\
\text { cytologically } \\
\text { normal } \\
(\mathrm{n}=117)\end{array}$} & $\begin{array}{l}\mathrm{CaCx} \\
(\mathrm{n}=89)\end{array}$ & $\begin{array}{l}\text { HLA DQB } 1 * 03 \text { allele positive vs. null } \\
\text { HLA DQB } 1 * 03 \text { heterozygosity vs. null } \\
\text { HLA DQB } 1 * 03 \text { homozygosity vs. null } \\
\text { HLA DQB } 1 * 03 \text { homozygosity vs. } \\
\text { non-homozygosity }\end{array}$ & $\begin{array}{l}0.92(0.44-1.91) \\
0.59(0.27-1.29) \\
2.50(0.94-6.66) \\
\mathbf{2 . 9 4 ( 1 . 4 9 - 5 . 8 1 )}\end{array}$ & $\begin{array}{l}0.822 \\
0.187 \\
0.066 \\
\mathbf{0 . 0 0 2}\end{array}$ \\
\hline & $\begin{array}{l}\text { HPV } 16 / 18 \\
\text { positive } \\
\mathrm{CaCx} \\
(\mathrm{n}=61)\end{array}$ & $\begin{array}{l}\text { HLA DQB } 1 * 03 \text { allele positive vs. null } \\
\text { HLA DQB } 1 * 03 \text { heterozygosity vs. null } \\
\text { HLA DQB } 1 * 03 \text { homozygosity vs. null } \\
\text { HLA DQB } 1 * 03 \text { homozygosity vs. } \\
\text { non homozygosity }\end{array}$ & $\begin{array}{l}0.60(0.28-1.30) \\
\mathbf{0 . 4 2}(\mathbf{0 . 1 8 - 0 . 9 6 )} \\
1.43(0.51-4.00) \\
\mathbf{2 . 3 2 ( 1 . 0 7 - 5 . 0 1 )}\end{array}$ & $\begin{array}{r}0.197 \\
\mathbf{0 . 0 4} \\
0.492 \\
\mathbf{0 . 0 3 3}\end{array}$ \\
\hline $\begin{array}{l}\text { HPV Positive } \\
\text { Cytologically } \\
\text { normal } \\
(\mathrm{n}=96)\end{array}$ & $\begin{array}{l}\mathrm{CaCx} \\
(\mathrm{n}=89)\end{array}$ & $\begin{array}{l}\text { HLA DQB } 1 * 03 \text { allele positive vs. null } \\
\text { HLA DQB } 1 * 03 \text { heterozygosity vs. null } \\
\text { HLA DQB } 1 * 03 \text { homozygosity vs. null } \\
\text { HLA DQB } 1 * 03 \text { homozygosity vs. } \\
\text { non-homozygosity }\end{array}$ & $\begin{array}{r}2.29(0.74-7.11) \\
1.39(0.46-4.24) \\
\mathbf{3 . 9 1 ( 1 . 0 8 - 1 4 . 2 0 )} \\
\mathbf{3 . 0 8}(\mathbf{1 . 1 8 - 8 . 0 8})\end{array}$ & $\begin{array}{l}0.153 \\
0.561 \\
\mathbf{0 . 0 3 8} \\
\mathbf{0 . 0 2 2}\end{array}$ \\
\hline $\begin{array}{l}\text { HPV } 16 / 18 \text { positive } \\
\text { Cytologically } \\
\text { normal } \\
(\mathrm{n}=73)\end{array}$ & $\begin{array}{l}\text { HPV } 16 / 18 \\
\text { Positive } \\
\text { CaCx } \\
(\mathrm{n}=61)\end{array}$ & $\begin{array}{l}\text { HLA DQB } 1 * 03 \text { allele positive vs. null } \\
\text { HLA DQB } 1 * 03 \text { heterozygosity vs. null } \\
\text { HLA DQB } 1 * 03 \text { homozygosity vs. null } \\
\text { HLA DQB } 1 * 03 \text { homozygosity vs. } \\
\text { non-homozygosity }\end{array}$ & $\begin{array}{l}0.97(0.29-3.22) \\
0.64(0.18-2.27) \\
2.04(0.49-8.45) \\
2.97(0.89-9.88)\end{array}$ & $\begin{array}{l}0.954 \\
0.493 \\
0.327 \\
0.076\end{array}$ \\
\hline
\end{tabular}

* Risk genotype vs. Non-risk genotype 
homozygosity of the allele was significantly associated with $\mathrm{HPV} 16 / 18$ positive $\mathrm{CaCx}\left(\mathrm{OR}_{\text {age- }}\right.$ adjusted $=2.32,95 \% \mathrm{CI}=1.07-5.01 ; \mathrm{p}=0.033)$. The heterozygous genotype, instead, showed a negative association with HPV16/18 positive $\mathrm{CaCx}$ over the null genotype $\left(\mathrm{OR}_{\text {age-adjusted }}=0.42\right.$, $95 \% \mathrm{CI}=0.18-0.96 ; \mathrm{p}=0.040)$. Compared to the HPV positive cytologically normal subjects, HLADQB $1 * 03$ homozygosity was significantly higher among $\mathrm{CaCx}$ cases compared to those with null genotype $\left(\mathrm{OR}_{\text {age-adjusted }}=3.91,95 \% \mathrm{CI}=1.08\right.$ $14.20 ; \mathrm{p}=0.038)$ and HLA DQB $1 * 03$ nonhomozygous genotypes $\left(\mathrm{OR}_{\text {age-adjusted }}=3.08,95 \%\right.$ $\mathrm{CI}=1.18-8.08 ; \mathrm{p}=0.022$ ). However, no significant association was observed when analysis was restricted within HPV16/18 positive subjects,

Table 3: Distribution of HLA DQB1*03 genotypes within $\mathrm{CaCx}$ cases of different age groups

\begin{tabular}{llcc}
\hline Case & HLA DQB $* 03$ & \multicolumn{2}{c}{ Age group (in years) } \\
\cline { 3 - 4 } & genotype & $<47$ & $\geq 47$ \\
\hline $\mathrm{CaCx}$ & null & 7 & 12 \\
$(\mathrm{n}=89)$ & & $(15.9)$ & $(26.7)$ \\
& HLA DQB $1 * 03$ & 16 & 20 \\
& heterozygous & $(36.4)$ & $(44.4)$ \\
& HLA DQB $1 * 03$ & 21 & 13 \\
& homozygous & $(47.7)$ & $(28.9)$ \\
\hline & Total & 44 & 45 \\
\hline
\end{tabular}

cases and controls.

The distribution of the HLA DQB $1 * 03$ genotypes (null, homozygous and heterozygous) among $\mathrm{CaCx}$ cases of age groups $<47$ years and 347 years is shown in Table 3 . The proportion of HLA DQB $1 * 03$ homozygous genotype was found to be significantly higher ( $\mathrm{p}$-value $=0.033$ from Fisher's Exact Test) for $\mathrm{CaCx}$ cases, whose age was $<47$ years $(47.7 \%)$ compared to those of age 347 years $(28.9 \%)$. Further analyses of the data to test the association of HLA DQB $1 * 03$ allele/genotypes with $\mathrm{CaCx}$ cases (irrespective of HPV) classified on the basis of age has been presented in Table 4. The HLA DQB1*03 homozygous genotype was found to be proportionately higher over non-homozygous genotypes among $\mathrm{CaCx}$ cases of age <47 years) compared to HPV negative cytologically normal controls $\left(\mathrm{OR}_{\text {age-adjusted }}=3.20\right.$, $95 \% \mathrm{CI}=1.53-6.66 ; \mathrm{p}=0.002)$. Overrepresentation of HLA DQB $1 * 03$ homozygosity, rather than nonhomozygosity, was also prominent among $\mathrm{CaCx}$ cases of the similar age group when compared to HPV positive cytologically normal subjects $\left(\mathrm{OR}_{\text {age-adjusted }}=2.59 ; 95 \% \mathrm{CI}=1.23-5.47 ; \mathrm{p}=0.011\right)$. There was no significant association between HLA DQB $1 * 03$ allele or the genotypes and $\mathrm{CaCx}$ cases, who were of age 347 years.

Table 4: Association of HLA DQB1*03 allele/genotypes with $\mathrm{CaCx}$ cases in different age groups

\begin{tabular}{|c|c|c|c|c|}
\hline \multirow[t]{2}{*}{ Control } & \multirow[t]{2}{*}{ Case } & \multirow[t]{2}{*}{ Analyses* } & \multicolumn{2}{|c|}{$\begin{array}{c}\text { OR }(95 \% \text { CI }) \\
\text { p-value } \\
\end{array}$} \\
\hline & & & $<47$ yrs & $\geq 47$ yrs \\
\hline \multirow{4}{*}{$\begin{array}{l}\text { HPV negative } \\
\text { cytologically } \\
\text { normal } \\
(\mathrm{n}=117)\end{array}$} & \multirow[t]{4}{*}{$\begin{array}{l}\mathrm{CaCx} \\
(\mathrm{n}=89)\end{array}$} & $\begin{array}{c}\text { HLA DQB } 1 * 03 \text { allele positive } \\
\text { vs. } \\
\text { null }\end{array}$ & $\begin{array}{c}1.29(0.51-3.27) \\
0.586\end{array}$ & $\begin{array}{c}0.67(0.30-1.50) \\
0.332\end{array}$ \\
\hline & & $\begin{array}{c}\text { HLA DQB } 1 * 03 \text { heterozygosity } \\
\text { vs. } \\
\text { null }\end{array}$ & $\begin{array}{c}0.77(0.28-2.11) \\
0.616\end{array}$ & $\begin{array}{c}0.56(0.24-1.33) \\
0.187\end{array}$ \\
\hline & & $\begin{array}{c}\text { HLA DQB } 1 * 03 \text { homozygosity } \\
\text { vs. } \\
\text { null }\end{array}$ & $\begin{array}{c}2.65(0.95-7.38) \\
0.058\end{array}$ & $\begin{array}{c}0.96(0.37-2.51) \\
0.193\end{array}$ \\
\hline & & $\begin{array}{c}\text { HLA DQB } 1 * 03 \text { homozygosity } \\
\text { vs. } \\
\text { non-homozygosity }\end{array}$ & $\begin{array}{c}3.20(1.53-6.66) \\
0.002\end{array}$ & $\begin{array}{c}1.42(0.65-3.10) \\
0.374\end{array}$ \\
\hline \multirow[t]{4}{*}{$\begin{array}{l}\text { HPV positive } \\
\text { normal cytology } \\
(\mathrm{n}=96)\end{array}$} & \multirow[t]{4}{*}{$\begin{array}{l}\mathrm{CaCx} \\
(\mathrm{n}=89)\end{array}$} & $\begin{array}{c}\text { HLA DQB } 1 * 03 \text { allele positive } \\
\text { vs. } \\
\text { null }\end{array}$ & $\begin{array}{c}1.57(0.62-4.01) \\
0.342\end{array}$ & $\begin{array}{c}0.82(0.36-1.85) \\
0.784\end{array}$ \\
\hline & & $\begin{array}{c}\text { HLA DQB } 1 * 03 \text { heterozygosity } \\
\text { vs. } \\
\text { null }\end{array}$ & $\begin{array}{c}1.03(0.37-2.85) \\
0.205\end{array}$ & $\begin{array}{c}0.75(0.31-1.79) \\
0.143\end{array}$ \\
\hline & & $\begin{array}{c}\text { HLA DQB } 1 * 03 \text { homozygosity } \\
\text { vs. } \\
\text { null }\end{array}$ & $\begin{array}{c}2.64(0.94-7.39) \\
0.061\end{array}$ & $\begin{array}{c}0.95(0.36-2.52) \\
0.195\end{array}$ \\
\hline & & $\begin{array}{c}\text { HLA DQB } 1 * 03 \text { homozygosity } \\
\text { vs. } \\
\text { non-homozygosity }\end{array}$ & $\begin{array}{c}2.59(1.23-5.47) \\
0.011\end{array}$ & $\begin{array}{c}1.15(0.52-2.54) \\
0.722\end{array}$ \\
\hline
\end{tabular}




\section{DISCUSSION}

HLAs play a significant role in host immunity as they participate in presenting intracellular and extracellular antigens to professional immune cells (Berkower 1996). Therefore, identifying specific HLA types associated with $\mathrm{CaCx}$ and the genes that encode them, are likely to be useful in predicting the susceptibility towards $\mathrm{CaCx}$ that is intimately associated with HPV infections. Associations between HLA DQw3 (class II type molecule) and $\mathrm{CaCx}$ have previously been observed among African- American (Gregoire et al. 1994), Caucasian (Wank and Thomssen 1991; Helland et al. 1992; Montoya et al. 1998), and Japanese ethnic populations (Nawa et al. 1995). No such report exists on Indian women inspite of the fact that $\mathrm{CaCx}$ appears to be the major cancer burden in these women. We therefore, undertook the present study in order to investigate the association, if any, of the immunogenetic factor HLA DQB $1 * 03$, with HPV16/18 related $\mathrm{CaCx}$ among Indian women from West Bengal.

We have earlier reported an overall prevalence of $85 \% \mathrm{HPV}$ infection, the prevalence of HPV 16/ 18 being $82 \%$, in invasive $\mathrm{CaCx}$. In the normal population of this region we also recorded $8.3 \%$ prevalence of HPV16/18 infection, which was predominant among those of age $£ 23$ years (Duttagupta et al. 2002). In this report we identified a significant difference in the distribution of HLA DQB1*03 genotypes between malignant and cytologically normal subjects, HPV negative or positive. The current study therefore is highly relevant in this context, for identifying those at risk of $\mathrm{CaCx}$ or HPV16/18 related $\mathrm{CaCx}$.

A significant association of HLA DQB $1 * 03$ homozygosity with $\mathrm{CaCx}$ or HPV16/18 positive $\mathrm{CaCx}$ (which accounts for $70 \%$ of the $\mathrm{CaCx}$ ) was observed. This was in comparison to the nonhomozygous genotypes of the allele. Mueller and Machulla (2002) also identified an increased frequency of homozygosity at HLA class II loci (DR/DQ) in female patients with chronic lymphocytic leukemia. As proposed by such researchers and others, homozygosity of HLA alleles are likely to provide a restricted repertoire of presented peptides, which could lead to impaired host defense. Similar phenomenon could therefore account for the susceptibility of subjects homozygous for HLA DQB $1 * 03$ alleles, towards CaCx or HPV16/18 positive CaCx, by members of HLA
DQB1*03 family of antigens, which share a common epitope.

Among the studies that found HLA DQB $1 * 03$ to be associated with $\mathrm{CaCx}$, Neuman et al. (2000) compared patients with family controls and reported that presence of DQB $1 * 0303$ allele increased the risk of $\mathrm{CaCx}$ in women who were HPV positive. Gregoire et al. (1994), on the otherhand, failed to show any association between HPV type in the tumor and HLA DQB1 *03 among African-American women. It may be noted that Mehal et al. (Mehal et al. 1994) have failed to show any association between HLA DQw3 and $\mathrm{CaCx}$ based on their study among women of United Kingdom.

In this study we have also noted a negative association of the HLA DQB $1 * 03$ heterozygosity, compared to null genotypes, with HPV16/18 positive $\mathrm{CaCx}$. This probably reflects a protective effect of heterozygosity of the allele. In fact, some studies have observed a selective advantage due to heterozygosity at human MHC (HLA class I and II) against infectious diseases like HIV infection and persistent hepatitis B virus infection (Carrington et al. 1999; Thursz et al. 1997). Odunsi et al. (1995) also reported that the risk towards CIN was lower in case of heterozygosity compared to homozygosity of HLA DQB $1 * 03$, the association being positive for both genotypes.

The differential role of the two genotypes could be due to various reasons. Firstly, the presence of a different allele along with HLA DQB $1 * 03$ at the same locus in the heterozygous condition may counterbalance the deficiency in immune responsiveness of HLA DQB $1 * 03$ allele coded antigens. Similar situation could also help in eliciting an immune response against a different epitope of the tumor or HPV related antigen. This may result in the lack of positive association with CaCx of HLA DQB $1 * 03$ heterozygosity. Furthermore, the possibility of a gene in linkage disequilibrium with HLA DQB1*03 in the homozygous condition may enhance the susceptibility towards development of $\mathrm{CaCx}$, of this genotype. Further work is therefore required to establish the differential role, if any, of the two HLA DQB $1 * 03$ genotypes.

It is also reflected in our study that the association between malignancy and HLA DQB $1 * 03$ homozygosity may not be independent of HPV16/18 infection. This is evident from the lack of any significant association between these two 
factors by a comparison between cases and controls, both positive for HPV16/18. The observation may be indicative of the association of HLA DQB1*03 homozygosity with HPV16/18 induced host cell antigen(s), specifically expressed in malignant cells.

This study also indicated that the risk of HLA DQB 1*03 homozygosity towards CaCx development, was restricted to those of age $<47$ years and absent in those of age ${ }^{3} 47$ years. It is well established that early age of onset is a risk factor for familial cancers. Therefore, HLA DQB $1 * 03$ homozygosity may have such genetic links also, which need to be explored in our population.

In summary, this study revealed that HPV infected (particularly, HPV16/18) and HLA DQB $1 * 03$ homozygous women of this population in West Bengal, India, appear to be at an enhanced risk to develop $\mathrm{CaCx}$. However, heterozygosity of HLA DQB $1 * 03$ may be protective for women infected with HPV16/18. Moreover, it also appeared that the genotypes of HLA DQB $1 * 03$, rather than the allele positivity, are likely to be important in determining the susceptibility to HPV infection and /or development of $\mathrm{CaCx}$ in these women. Further elucidation of the association of specific alleles of HLA DQB1*03 with HPV16/18 related CaCx is needed, which is underway. We conclude that the findings are likely to add new dimension to the epidemiological background of $\mathrm{CaCx}$ in this region.

\section{ACKNOWLEDGEMENTS}

We are grateful to Dr. Chandralekha Duttagupta (former Head of Biochemistry Unit) Professor P.P. Majumdar (Human Genetics Unit) and Dr. D. Sengupta (Statistics and Mathematics Unit) of the Indian Statistical Institute, Kolkata, India, for their valuable suggestions and discussions regarding statistical analysis of the data; to Dr. S. Ghosh (Gynecologist), and members of the GYN Out Patient Department, Cancer Centre Welfare Home and Research Institute, Thakurpukur; Drs. S. Chaudhuri, R. Das and members of CINI and Dr. Nirmal Saha (Gynecologist) for their kind help in the collection of samples; Dr. S. Roy, Director, Pathological laboratory, Quadra Medical Services, for his help in histopathologic interpretations. We recognize the help of all members of the Human Genetics Unit, Indian Statistical Institute.

\section{REFERENCES}

Allen M, Kalantari M, Ylitalo N, Pettersson B, Hagmar B, Scheibenpflug L, Johansson B, Petterson U, Gyllensten U 1996. HLA DQ-DR haplotype and susceptibility to cervical carcinoma: indications of increased risk for development of cervical carcinoma in individuals infected with HPV 18. Tissue Antigens, 48: 32-37.

Apple RJ, Erlich HA, Klitz W, Manos MM, Becker TM, Wheeler CM 1994. HLA DR-DQ associations with cervical carcinoma show papillomavirus type specificity. Nature Genet, 6: 157-162.

Berkower I 1996. T-cell recognition of proteins and the major histocompatibility complex. In: Sell S, Berkower I, Max EE, (Eds.): Immunology, Immunopathology, and Immunity. Stamford, CT: Appleton and Lange, pp. 141-167

Bugawan TL, Erlich HA 1991. Rapid typing of HLA DQB1 DNA polymorphism using non-radioactive oligonucleotide probes and amplified DNA. Immunogenetics, 33: 163-170.

Carrington M, Nelson GW, Martin MP, Kissner T, Vlahov D, Goedert J, Kaslow R, Buchbinder S, Hoots K, O'Brien S 1999. HLA and HIV-1: Heterozygote Advantage and $\mathrm{B} * 35-\mathrm{Cw}^{*} 04$ Disadvantage. Science, 283: $1748-1752$.

Duttagupta C, Sengupta S, Roy M, Sengupta D, Chakraborty S, Bhattacharya P, Roy S, Ghosh S 2002. Oncogenic Human papillomavirus (HPV) infection and uterine cervical cancer: a screening strategy in the perspective of rural India. Eur $J$ Cancer Prev, 11: 447-456.

Glew SS, Stern PL, Davidson JA, Dyer PA 1992. HLA antigens and cervical carcinoma. Nature, 356: 22 .

Glew SS, Duggan-Keen M, Ghosh AK, Ivinson A, Sinnott P, Davidson J, Dyer PA, Stern PL 1993. Lack of association of HLA polymorphisms with human papillomavirus-related cervical cancer. Hum Immunol, 37: 157-164.

Gregoire L, Lawrence WD, Kukuruga D, Eisenbrey AB, Lancaster WD 1994. Association between HLA DQB1 alleles and risk for cervical cancer in African American women. Int J Cancer, 57: 504-507.

Helland A, Borresen AL, Kaern J, Ronningen KS, Thorsby E 1992. HLA Antigens and cervical carcinoma. Nature, 356: 23.

Helland A, Borresen AL, Kristensen G, Ronningen KS 1994. DQA1 and DQB1 genes in patients with squamous cell carcinoma of the cervix: relationship to human papillomavirus infection and prognosis. Cancer Epidemiol Biomarkers Prevent, 3: 479-486.

Hosmer DW, Lemeshow S 1989. Applied Logistic Regression. New York: John Wiley \& Sons.

Mehal WZ, Lo YM, Herrington CS, Evans MF, Papadopoulos MC, Odunsi K, Ganesan TS, McGee J O’D, Bell JI, Fleming KA 1994. Role of human papillomavirus in determining the HLA associated risk of cervical carcinogenesis. J Clin Pathol, 47: 1077-1081.

Montoya L, Saiz I, Rey G, Vela F, Clerici-Larradet N 1998. Cervical carcinoma: human papillomavirus infection and HLA-associated risk factors in the 
Spanish population. Eur J Immunogenet, 25: 329-337. Mueller LP, Machulla HKG 2002. Increased frequency of homozygosity for HLA class II loci in female patients with chronic lymphocytic leukemia. Leukemia and Lymphoma, 43: 1013-1019.

Nawa A, Nishiyama Y, Kobayashi T, Wakahara Y, Okamoto T, Kikkawa F, Suganuma N, Goto S, Kuzuya K, Tmoda Y 1995. Association of Human Leukocyte Antigen-B1*03 with cervical cancer in Japanese women aged 35 years and younger. Cancer, 75: 518-521.

Neuman RJ, Huettner PC, Li L, Mardis ER, Duffy BF, Wilson RK, Rader JS 2000. Association between DQB1 and cervical cancer in patients with human papillomavirus and family controls. Obstet Gynecol, 95: 134-140.

Odunsi K, Terry G, Ho L, Bell J, Cuzick J, Ganesan TS
1995. Association between HLA D Q B $1 * 03$ and cervical intraepithelial neoplasia. Mol Med, 1: 161-171.

Thursz MR, Thomas HC, Greenwood BM, Hill AV 1997. Heterozygote advantage for HLA class II type in hepatitis B virus infection. Nature Genet, 17: 1112 (erratum in Nature Genet 1998, 18, 88.).

Villa LL 1997. Human papillomaviruses and cervical cancer. Adv Cancer Res, 71: 321-341.

Walboomers JM, Jacobs MV, Manos MM, Bosch FX, Kummer JA, Shah KV, Snijders PJ, Peto J, Meijer CJ, Munoz N 1999. Human papillomavirus is a necessary cause of invasive cervical cancer worldwide. Journal of Pathology, 189: 12-19.

Wank R, Thomssen C 1991. High risk of squamous cells carcinoma of the cervix for women with HLADQw3. Nature, 352: 723-725. 